\title{
Germination response to phytotoxicity of Impatiens parviflora
}

\section{Ligita Baležentienè}

Institute of Ecology and Environment, Vytautas Magnus University, Studentu 11, Akademija 53361, Kaunas district, Lithuania
Biochemical interactions in ecosystems have revealed the ecophysiological significance of secondary metabolites. Biochemical interaction underlies the novel weapons hypothesis thus presenting one of numerous explanations for the spread of invasive species. The knowledge of how invasive species spread in a new environment might be important for their management control. This study was aimed to determine the total phenolics content in Impatiens parviflora (I parv) and evaluate the germination response of monocot and dicot species to phytotoxicity. Wheat and rapeseed germination response to allelopathic activity of worldwide invasive Impatiens species (Balsaminaceae), namely, I. parviflora (native to Central Asia) was assessed ex situ at Aleksandras Stulginskis University in 2016. Phenolic content ranged between 0.32 and $5.53 \mathrm{mg} \mathrm{g}^{-1}$ in aqueous extracts of donor Impatiens. These allelopathic compounds are phytotoxic and usually reduce the growth of neighbouring plants. The data revealed their inhibition of germination and the seedling growth of both recipient species. However, the germination response was different for each recipient species due to different morphology of the seed coat. Inhibition of Impatiens extracts was recorded stronger for rapeseed (R) germination (mean 51.0\%) than that for wheat (W) germination (mean 23.8\%), possibly due to different seed coat anatomy and, consequently, its permeability. Therefore the strongest inhibition (93.0\%) was recorded for rapeseed germination (4.5\%) in $0.2 \%$ flower and fruit+seed extract of I. parviflora. Parameters of wheat seedlings also exhibited a weaker response to the extract of I. parviflora than that of rapeseed. The data revealed that Impatiens parviflora might negatively affect the regeneration of neighbouring native species in invaded habitats.

Keywords: Allelopathy, germination, phenolics, Impatiens parviflora

\section{INTRODUCTION}

Small balsam (Impatiens parviflora DC., Balsaminaceae) is a native herb to Central Asia where it

* Corresponding author. Email: ligita.balezentiene@vdu.lt commonly inhabits forest understories on shaded river banks and mountain slopes (Weber, 2003). Though only a small ratio of introduced species become invasive over their native range, I. parviflora is one of the most widespread invasive plants in the temperate and boreal regions of Europe 
where it thrives in microhabitats of different environmental conditions (Lambdon et al., 2008; Ćuda et al., 2014). A number of alien species continuously increases at disturbed and more productive or temporarily nutrient-rich habitats (Blumenthal, 2005; Chytrý et al., 2008; Callaway, 2002). Usually, small balsam (I. parviflora; abbr. I parv) forms large pure populations and spreads widely by seeds in European forests. It prefers shaded and moist nutrient-rich soils of neutral-acidic conditions. It thrives in beech and alder forests, but can also be found in parks, along hedgerows, on forest edges, in waste grounds and ruderal habitats. European populations of I. parviflora have been known as floor vegetation species that spread across natural and semi-natural temperate forests or in human-made habitats (Reczyńska et al., 2015). In the last decade, numerous investigations have been devoted to the ecological performance of I. parviflora, improving the knowledge of the invasiveness of the species and its impact on native vegetation. In Lithuania, I parv was first identified in 1934; here it outcompeted the native species I. noli-tangere.

Successful spread of introduced alien plant species in new territories might occur due to their rapid growth and reproduction, the ability to colonize disturbed habitats, a short life cycle, early flowering and seeding, production of large quantities of seeds and vegetative propagules, different phenology from native species, and disease- and pest-resistance. Furthermore, recently the ecological significance of secondary metabolites in ecosystem interactions has been approved (Blumenthal, 2005). Production and release of allelopathic compounds that have harmful effects on neighbour plant in their introduction range are considered as one of the potential drivers of plant invasion. The phenomenon of allelopathy is an alternative explanation for the recruitment and dispersion of invasive species in undisturbed communities achieved by the release of novel, yet unexperienced in the invaded ecosystem, phytochemicals, such as allelopathic compounds that have phytotoxic or at least fitnessreducing effects on plant neighbours. Studies of biochemical interaction between organisms, or allelopathy, attempted to explain the significance of the role of the diversity of secondary metabolites in the functionality of organisms and ecosystems (Inderjit, Nilsen, 2003). However, biochemically mediated interferences are those of many interactions (competition, microbial nutrient immobilization, mycorrhizal activity etc.) that exist in ecosystems and the distinction of which is difficult if not impossible (Callaway, Ridenour, 2004).

Notwithstanding the intensive spread of vegetative species, this study is aimed on research into biochemical facilities that are likely to be involved in the invasivness of this species. It is focused on research on the phytotoxicity of allelochemicals that is likely to be involved in the invasion success of the invasive species. Assessment of the most common secondary compounds in the plant, i.e., total phenolic content (TPC) of I. parviflora extract and its suppression of germination of perennial ryegrass (monocots) and winter rapeseed (dicots) seed was carried out ex situ.

\section{MATERIALS AND METHODS}

The plant data set comprised Impatiens parviflora (abbr. I parv) as an invasive species on the EPPO list (2006) also presented in Lithuania. The species is included in the Lithuanian national list of invasive species (Invaziniu Lietuvoje rūšių sąrašas, 2016). The spread of I parv can be attributed to autochory which along with high germination, seedling emergence, and seedling frost resistance has promoted the species to become highly invasive in Central and Western Europe. A plant data was pre-selected for screening in the central part of Lithuania, near the busy motorway Via Baltica, an invasion corridor. The species samples were collected for the assessments along the banks of the Nemunas and the Marvele riv-

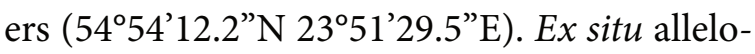
pathic activity of invasive Impatiens parviflora (Balsaminaceae) was assessed at Aleksandras Stulginskis University in 2016.

Total phenolic content (TPC) was determined in extract samples using Singleton and 
Rossi (1965) photocolorimetric method using Folin-Ciocalteu reagent (Merck, Darmstadt, Germany) and the standard curve with chlorogenic acid (Sigma, Aldrich, Germany). The samples were analysed in two replications. Identification and quantification of individual target polyphenolic compounds was carried out using UV-Vis spectrophotometer (Bechman DU-40, Germany). In crude extracts of each fraction, TPC was expressed as a fresh weight basis in $\mathrm{mg}$ per g chlorogenic acid equivalent.

Germination was recorded under seed germination $>50 \%\left(\mathrm{G}_{50}\right)$ in distilled water (control). Thereafter, the $\mathrm{G}_{50}$ rate was equated to $100 \%$. This method enables to evaluate not only inhibitory, but also stimulatory effects of extracts. Fastgerminating and high germination (98\%) winter oil rapeseed, (Brassica napus L.) cv. Cult and spring wheat (Triticum aestivum L.) cv. Hamlet were chosen as recipient plants. One hundred recipient seeds were placed on filter paper in each of five Petri dishes (6-cm diameter); each dish was supplemented with $5 \mathrm{ml}$ aqueous extracts $(0,0.02,0.05,0.1$, and $0.2 \% \mathrm{w} / \mathrm{v})$ and kept at $26^{\circ} \mathrm{C}$ for $16 \mathrm{~h}$. Treatments were replicated four times. Germination was considered when radicle emerged from the seed coat.

Statistical analysis. Significant differences among the means were determined using F-test (ANOVA). The results of allelopathic effects were statistically evaluated by using the statistical package STATISTICA (StatSoft Inc., 2004). The results regarding phenols concentration, germination, and seedlings parameters are presented as mean \pm SD of four independent analyses at the $p<0.05$ significance level.

\section{RESULTS AND DISCUSSION}

The extracted phenolic content varied between 0.73 and $5.47 \mathrm{mg} \mathrm{g}^{-1}$ and significantly $(p=0.000)$ depended on the extract concentration in I parv extracts (Fig. 1). Conversely, the differences in TPC accumulation in different plant parts were insignificant $(p=0.649$, Fig. 2). Mean TPC in root and flower was 2.574 and $2.559 \mathrm{mg} \mathrm{g}^{-1}$, respectively, and insignificantly higher $\left(1.756 \mathrm{mg} \mathrm{g}^{-1}\right)$ in leaf+stem.
Although phenolics constitute a large group of phenolic compounds in plants, its content was recorded rather low in I parv harvested in temperate climate of Lithuania as recorded by former researchers (Szewczyk, Olech, 2017). A relatively low accumulation of TPC might be related with favourable conditions lacking pests in invaded habitats since these secondary metabolites are generally produced as a response to environmental stress (light, temperature and pollution) or pest damages (Jarcuskasca et al., 2016; Padda, Picha, 2008). In temperate climate, at chilling winter temperatures, the permeability of cell membranes and the activity of membrane-bound enzymes are changed, thus leading to an accumulation of toxic intermediates in cells. This creates physiological stress in plant cells and considerably increases the level of phenylalanine ammonia lyase (PAL) enzyme (involved in phenolic biosynthesis catalysing the reductive deamination of phenylalanine to form cinnamic acid).

Consistently with previous research with other herbaceous plants (Callaway, Ridenour, 2004, Hanley, Whiting, 2005), phenolics induce the phytotoxicity of I parv also, thus inhibiting the germination of both recipient species (Figs. 1, 2). Mean germination was $71.1 \%$ of wheat and $43.2 \%$ of rapeseed which indicated their different sensitivity to I parv phytotoxicity might be attributed to a different seed coat anatomy and thus its permeability. Concomitant to Moise et al. (2005) that germination existed different due to different structure of seed coat (testa), the thick, lignified coats of wheat grain were scarcely impermeable to extracts, thereby maintaining their ability to reduce the phenolic inflow to the embryo resulting in higher wheat germination than rapeseed. Significantly, minimal wheat germination $(62 \%, p=0.000)$ was recorded in the flower extracts of the strongest concentration of $0.02 \%$. Germination of rapeseed decreased $(p=0.0789)$ from 77.5 to $4.5 \%$ with increasing concentration of extracts.

At the habitat level, I parv inhibition of germination ex situ might also ensure suppression of the initial species recruitment including germination, the seedling growth and establishment, 

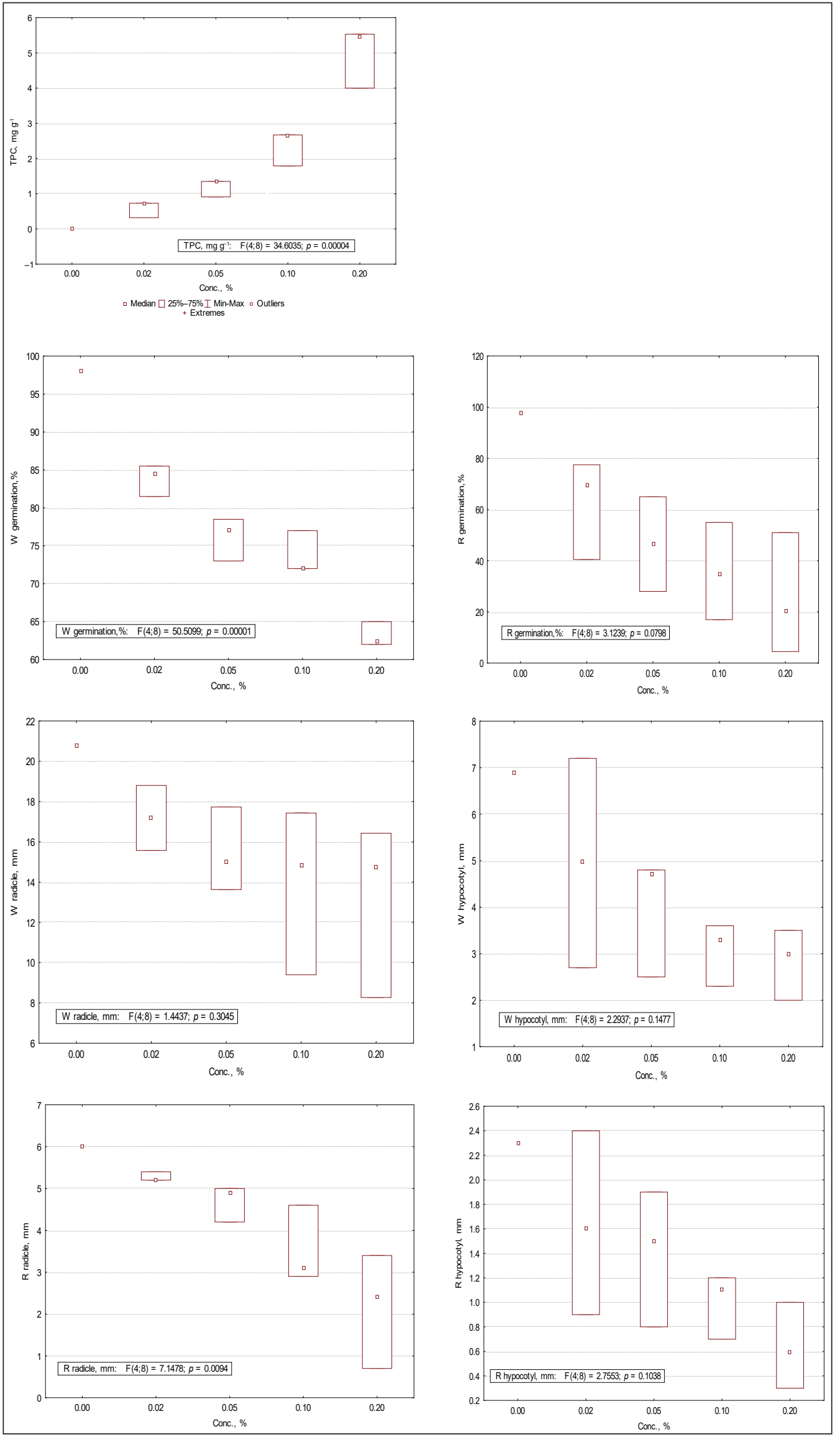

Fig. 1. Distribution of TPC and seedling parameters in extracts of different concentration 


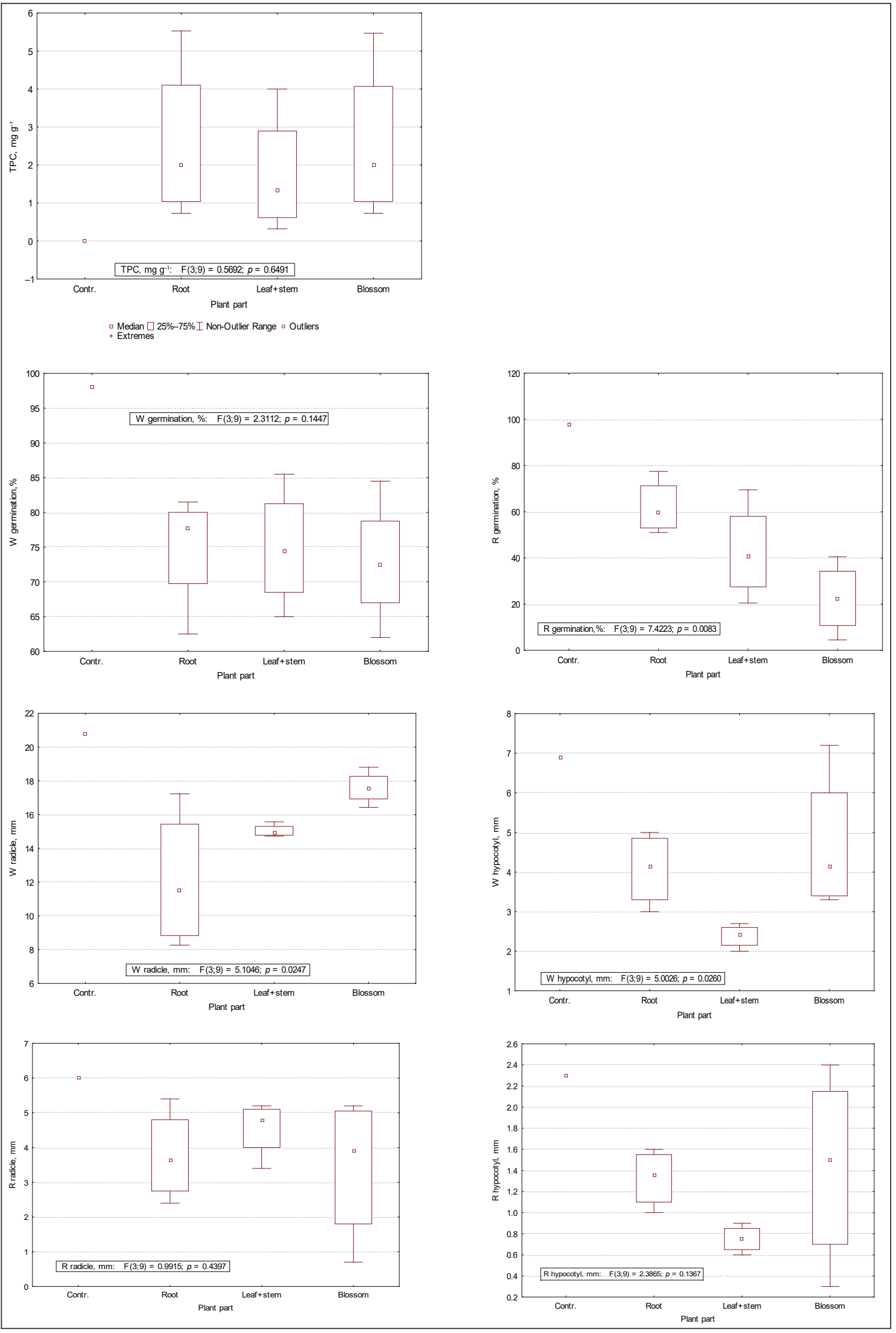

Fig. 2. Scattering of TPC and seedling parameters in extracts of different plant parts 
thus producing a negative impact on the overall development and regeneration of a plant community. These processes can be influenced by several ecological parameters synergically impacting plant regeneration, but only few studies deal with plant recruitment and regeneration taking into account the concomitant effect of environment indices.

Extract concentration of I parv also inhibited the seedling growth (Fig. 1). Nonetheless, the significant inhibition was recorded only for rapeseed radicle $(p=0.0094)$.

I parv extracts produced from different plant parts exhibited altered inhibition of the seedling radicle and hypocotyl length (Fig. 2). However, the extract inhibition was significant only for wheat radicle $(p=0.0247)$ and hypocotyl $(p=0.0260)$. In addition, significant differences were observed for parameters of wheat seedlings only in the extracts of leaf+stem and the flower.

The results suggest that the invasive plant species I. parviflora may acquire spreading advantage in new territories due to its ability to inhibit recipient germination and seedling parameters.

\section{CONCLUSIONS}

The present allelopathic research aimed to determine the allelochemical activity as a potential ecological factor driving plant invasions. While previous studies had indicated that Impatiens parviflora accumulated numerous allelochemicals, our findings revealed that invasive species contained phenolics toxic to recipient germination and supressing seedlings growth. Consequently, phytotxicity of I. parviflora might impact the germination and regeneration or recruitment of neighbouring species in invaded habitats. Thus, small balsam might considerably reduce species diversity or locally out-compete the native plants in habitats. The revealed allelochemical phytotoxicity of Impatiens parviflora should be considered as a partial explanation of its high aggressiveness, and thus may help to improve our knowledge of the invasiveness of this species.

\section{ACKNOWLEDGEMENTS}

Author would like to thank the Institute of Ecology and Environment for the lab space and for technical support and assistance.

Received 30 May 2018

Accepted 13 March 2019

\section{References}

1. Blumenthal D. Ecology-interrelated causes of plant invasion. Science. 2005; 310: 243-4.

2. Callaway RM. The detection of neighbours by plants. Trends Ecol Evol. 2002. 17(3): 104-5.

3. Callaway RM, Ridenour WM. Novel weapons: a biochemically based hypothesis for invasive success and the evolution of increased competitive ability. Front Ecol Environ. 2004; 2: 436-3.

4. Chytrý M, Maskell LC, Pino J, Pyśek P, Vilà M, Font X, Smart SM. Habitat invasions by alien plants: a quantitative comparison among Mediterranean, subcontinental and oceanic regions of Europe. J Appl Ecol. 2008; 45: 448-58.

5. Ćuda J, Skálová H, Janovský Z, Pyśek P. Habitat requirements, short-term population dynamics and coexistence of native and invasive Impatiens species: a field study. Biol Invasions. 2014; 16: 177-90.

6. di Castri F, Hansen AJ, Debussche M, editors. Biological invasions in Europe and the Mediterranean Basin. Dordrecht: Kluwer Academic Publishers; 1990. p. 319-416.

7. Inderjit, Nilsen ET. Bioassays and Field Studies for Allelopathy in Terrestrial Plants: Progress and Problems. Critic Rev in Plant Sc. 2003; 22: 221-38.

8. Jarcuskasca B, Slezák M, Hrivnákc R, Senko D. Invasibility of alien Impatiens parviflora in temperate forest understories. Flora. 2016; 224: 14-23. 
9. Lambdon PW, Pyśek P, Basnou C, Hejda M, Arianoutsou M, Essl F, Jarośík V, Pergl J, Winter M, Anastasiu P, Andriopoulos P, Bazos I, Brundu G, Celesti-Grapow L, Chassot P, Delipetrou P, Josefsson M, Kark S, Klotz S, Kokkoris Y, Kuehn I, Marchante H, Perglová I, Pino J, Vilà M, Zikos A, Roy D, Hulme PE. Alien flora of Europe: species diversity, temporal trends, geographical patterns and research needs. Preslia. 2008; 80: $101-49$.

10. Invazinių Lietuvoje rūšiu sąrašas. 2016; D1810/128/11/2016. LR Aplinkos ministerija, Vilnius. Lithuanian.

11. Moise JA, Han S, Gudynaite-Savitch L, Johnson DA, Miki BLA. Seed coats: structure, development, composition and biotechnology. In vitro Cell Dev Biol Plant. 2005; 41: 620-44.

12. Padda MS, Picha DH. Effect of low temperature storage on phenolic composition and antioxidant activity of sweetpotatoes. Postharvest Biol Technol. 2008; 47: 176-80.

13. Reczyńska K, Ŝwierkosz K, Dajdok Z. The spread of Impatiens parviflora DC. in Central European oak forests - another stage of invasion? Acta Soc Bot Pol. 2015; 84: 401-11.

14. StatSoft Inc. 2004. STATISTICA (Data analysis software system), Version 7. www.statsoft.com.

15. Szewczyk K, Olech M. Optimization of extraction method for LC-MS based determination of phenolic acid profiles in different Impatiens species. Phytochemistry Letters. 2017; 20: 322-30.

16. Weber E. Invasive plant species of the world. A reference guide to environmental weeds. Oxon: CABI Publishing; 2003. 548 p.

\section{Ligita Baležentienè}

\section{DAIGUMO ATSAKAS İ IMPATIENS PARVI- FLORA FITOTOKSIŠKUMĄ}

\section{Santrauka}

Biocheminè sąveika ekosistemose atskleidžia antrinių metabolitų ekofiziologinę reikšmę. Biochemine sąveika pagrindžiama "naujo ginklo“ hipotezè, kuri gali paaiškinti daugelio invazinių rūšių plitimą. Suprasti invazinių rūšių plitimo mechanizmą naujoje aplinkoje yra svarbu, kai siekiama siekiant jų kontrolès. Šio tyrimo tikslas buvo nustatyti Impatiens parviflora bendrą fenolių kiekị ir ịvertinti vienskilčiu ir dviskilčiu akceptorių daigumo atsaką fitotoksiškumui. Kviečių ir rapsų daigumo atsakas ex situ ị invazinès Impatiens parviflora rūšies (kilusios iš Centrinès Azijos) alelopatini aktyvumą buvo tirtas Aleksandro Stulginskio universitete 2016 metais. Impatiens parviflora vandeniniuose ekstraktuose fenoliniu junginių kiekis svyravo tarp 0,32 ir $5,53 \mathrm{mg} \mathrm{g}^{-1}$. Šie alelopatiniai junginiai yra fitotoksiški ir paprastai slopina aplinkinių augalų augimą. Tyrimo duomenys patvirtino jų slopinanti poveiki abiejų recipiento rūšių daigumui ir daigų augimui, tačiau dèl skirtingos sèklos luobelès morfologijos ir nevienodo jos pralaidumo kiekvienos rūšies daigumo atsakas buvo kitoks: Impatiens parviflora ekstraktas stipriau inhibavo rapsų (vid. 51,3\%) nei kviečiu (23,8 \%) daigumą. Rapsų daigumą stipriausiai inhibavo (93,5 \%) 0,2 \% I. parviflora žiedų ir vaisių + sèklų ekstraktai. Duomenys rodo, kad Impatiens parviflora gali neigiamai veikti kaimyninių vietinių rūšių atsikūrimą infekuotose augimvietèse.

Raktažodžiai: alelopatija, daigumas, fenoliniai junginiai, Impatiens parviflora 